\title{
Some aspects of the early evolution of the Appointed Factory Doctor Service*
}

\author{
JAMES A. SMILEY \\ Department of Social Medicine, Queen's University, Belfast
}

\begin{abstract}
Smiley, J. A. (1971). Brit. J. industr. Med., 28, 315-322. Some aspects of the early evolution of the Appointed Factory Doctor Service. The appointment of certifying surgeons marks the beginning of the recognition by the State of its responsibility for the supervision of the health and welfare of young people in industry. The importance of the rôle played by Leonard Horner, one of the first four inspectors of factories, is discussed. Some of the problems and vicissitudes of the service in the 19th century are outlined and it is suggested that the system is inappropriate to the needs of the present. Legislation which would integrate all the agencies which are concerned with the well-being of young people, including the Appointed Factory Doctor Service, should be actively considered.
\end{abstract}

James Mackenzie: whose life and work we honour, was General Secretary of the Y.M.C.A. National Council in Scotland. His contacts with working class boys led him to believe that legislation to protect the health of the worker could be made effective only through education by leading him to an understanding of the hazards involved. So in 1922 Mackenzie was instrumental in forming in Scotland the Industrial Education Council 'with the object (among others) of educating the industrial worker on the diseases and sicknesses to which they are liable with a view to their mitigation and prevention'. ${ }^{1}$ Such was the interest aroused in Scotland that requests for an extension of its activities to the rest of the country were met (with the support of Professor J. Glaister and Sir Robert Phillips) by its conversion to The Industrial Health Education Society for the United Kingdom. ${ }^{2}$ Its work was mainly carried out by the organization of talks and lectures all over the country and some idea of the scope of its activity may be gauged by the fact that an average of 400 talks were being given each year. ${ }^{3}$ As the result of changes brought about by the 1939-45 war it was decided to wind up the Society. In its later years the British Medical Association had *B.M.A. Mackenzie Industrial Health Lecture 1970, delivered at Trinity College, Dublin. cooperated actively and had given the Society the hospitality of B.M.A. House for its headquarters. Mackenzie was in failing health, so at a meeting held in 1944 in Edinburgh where the original Society had been founded, it was decided to hand over to the B.M.A. the remaining funds for the establishment of a lectureship on the relation of health to industry, to be associated with the name of James Mackenzie who had started the Society and continued as its organizer. He died in 1944 and this lecture has been delivered biennially since 1946 . This brief outline of the work of the man whom now we remember reminds us that advances in industrial health and well-being have been achieved by the cooperation of doctors and laymen of many different disciplines. It is an interesting study to observe how the framework for these achievements has been gained.

Since the 16th century it had been accepted that the primary duty of statesmen was to safeguard the prosperity and well-being of the nation as a whole. The idea that it was proper for the Government to regulate the minutiae of commercial activities was fully accepted. With the rise of the Factory System and the formulation of the doctrine of laissez-faire, supported by the grim economic theories of Adam Smith, Ricardo's philosophy of self interest, and the pessimistic population studies of Malthus, human 
selfishness was restrained only very occasionally by the working of conscience. Whereas the mediaeval labour statutes, e.g., Statute of Artificers 1563, and the ordinances of the craft guilds had given some measure of protection to the workers against exploitation, with the disintegration of mediaeval society many of these conventions were no longer relevant. The fact, of course, is that the laws were not specifically designed for protection of the working population. They were designed to promote the interests of the masters and there was a presumption that what was beneficial for them was in the interests of all. 'The guild prohibitions of work at night seem to have been partly due to the desire to maintain a high standard of quality in the product which might be endangered ,by night work, the prescription of holidays partly to religious motives and both probably also to the idea that as the normal citizen went to church on festivals and slept at night, it was unfair that he should be injured in his business by the competition of those who infringed these orderly customs.' ${ }^{4}$ The Elizabethan Poor Law of 1601 required that destitute children and orphans should be apprenticed to some trade. Houses of industry for instructing these children in spinning and weaving were a favourite charitable hobby of the 17 th and 18 th centuries and the children were subsequently bound apprentice to employers. There was a domesticity and intimacy about the arrangements which disappeared with the coming of the factory system-although indeed the custom persisted much longer in Ireland, probably, of course, because the factory system was so much later in coming to this country. Bishop D'Arcy, whom some older members of this audience may remember, in his autobiography describes with approbation two such workshops still in existence at the beginning of this century which had been set up in Co. Monaghan by the wives of two clergymen for the instruction of girls, one in the art of crochet lacemaking and the other in the manufacture of Carrickmacross and Inishmacsaint lace. ${ }^{5}$

With the advent of water and later of steam power and mechanization the aggregations of people leaving the land to settle near the sources of power, the rise of the mercantile class, the ruthless, hard and selfish exploitation of the labouring classes, and the rejection by most millowners (with a few honourable exceptions) of any responsibility for the well-being of their workpeople, their condition, especially that of the children, rapidly deteriorated. It was when the interests of the employing classes around Manchester were threatened by epidemic disease originating at a cotton mill at Radcliffe that the local justices in 1784 took action. They invited Dr. Thomas Percival, a leading physician in the area, to 'investigate the nature and the circumstances of the outbreak'. With his colleagues and leading citizens he formed the Manchester Board of Health. This Board, through authoritative reports, made recommendations for the control of such epidemics by the establishment of isolation hospitals. They also urged the need for the improvement of environmental conditions in mills and factories and for the diminution of working hours, especially for children and women. In pursuance of these objects, the Government in 1802 passed the Health and Morals of Apprentices Act, ${ }^{6}$ the First Factory Act. This audience does not need to be reminded of the plight of the children at that time. Because of the coming of mechanization manufacturers found that many processes could readily be carried on without the labour of men. With growing male adult unemployment the demand for juvenile labour increased, and because of poverty, in the manufacturing towns, parents reckoned each child a supplement to their incomes. In the southern towns and in agricultural parishes the local authorities disembarrassed themselves of a burden by selling pauper children, under the name of apprentices, to Lancashire and Yorkshire manufacturers. These children, often housed in dormitories attached to the mills, were virtually unprotected. They entered the mills at an incredibly early age. Daniel Defoe mentions 4 years and a Mr. John Moss gave evidence to the Sir Robert Peel Committee in 1816 that the apprentices in a Preston mill mostly came from London and were between the ages of 7 and 11. Children of this age were easily cowed into submission and they were entirely at the mercy of their employers who, because of the prevailing philosophy and practice, assumed them to be free agents. The reports of the various commissions and committees in which the Victorian era abounds present horrifying evidence of the disastrous effects of the factory system. It astonishes me that Sir Arthur Bryant could entitle his book on the period 'The Age of Elegance'-a period which the Hammonds felt impelled to call 'The Bleak Age'.

The Act of 1802 required that apprentices should not be employed for more than 12 hours a day nor must they work between 9.00 p.m. and 6.00 a.m. They were to receive instruction in reading, writing, and arithmetic and they were to go to church once a month. They were to have a suit of clothes each year and they were not to sleep more than two in a bed. Factories were to be whitewashed twice a year and the windows were to be sufficient to secure adequate ventilation. The factory premises were to be inspected by visitors appointed at the Quarter Sessions and if any infectious disease occurred in the factory the visitors were empowered to call in a physician who was to make periodical reports on the progress of the disorder, his fees to be paid by the mill owner. ${ }^{7}$ I find this last provision to be of some passing interest in view of the correspon- 
dence which 47 years later passed between the Home Office and J. A. Stuart, one of the first factory inspectors. On 8 January 1849 Stuart, having received a communication from an under secretary, H. Waddington, concerning an outbreak of cholera in Glasgow, replied that the 'only gentlemen who alone are officially in discharge of any duty connected with the Factory Acts, viz., Mr. Charles Balfour, subinspector of factories, and Messrs David Cunningham, Joseph Fleming, and James Stewart, certifying surgeons, .... I have directed them to give their immediate and best assistance in endeavouring to check the destructive progress of the epidemic cholera. ... They are trustworthy and intelligent men.' 8

Alex Bain, assistant surgeon to the General Board of Health on 15 September 1849, writing to Sir George Gray at the Home Office, said 'the arrangements made in Glasgow and Dundee for the daily examination of the operatives in each factory during the prevalence of cholera were of utmost importance in preventing incipient cases of cholera from passing into the malignant and fatal stages of the disease and I am to express the desire of the Board that similar arrangements be made, through the Inspectors for the factories in those places of Yorkshire and Lancashire at present affected or threatened with an attack of the disease.' ${ }^{\prime}$ On 2 October 1849, an epidemic having broken out in Lancashire and Yorkshire, the Home Office asked that 'the same plan be adopted which was carried out in various towns in Scotland under the direction of Mr. Stuart but that they are not aware in what mode the certifying surgeons in those towns were remunerated for their services.' 10

When Leonard Horner wrote to his certifying surgeons he added 'as you will perceive, the letter from the Under-secretary of State says nothing as to your remuneration for such visits but I think you need have no doubt of the Government doing all that is just and right in that respect'. It might be an interesting exercise sometime to find out how indeed they were remunerated, by whom they were remunerated, and why the principle established in the 1802 Act was in doubt.

My purpose, however, in spending so much time on the 1802 Act, 'an Act for the Preservation of the Health and Morals of apprentices and others, employed in cotton or other mills and cotton and other factories' is not to discuss the amount or method of remuneration but to show that even from the early days of factory law those concerned were legislating not only to improve working conditions and make them more safe, not only to safeguard the health of the community in general, they were drafting a Bill quite evidently acknowledging that the morals and the education of young people were matters of interest, concern, and responsibility. It is in the tradition of factory legislation that people are regarded not as being physical automata or mere 'factory hands' but in all their fullness as human beings. The State, in theory at least, seemed to accept one of the principles later enunciated in the Constitution of the World Health Organization that 'Health is a state of complete physical, mental and social well-being and not merely the absence of disease or infirmity'. . . . 'Healthy development of the child is of basic importance; the ability to live harmoniously in a changing total environment is essential to such development'. ${ }^{12}$

The 1802 Act, however, was observed mainly in the breach and there is considerable evidence not only that many magistrates were unaware of its provisions but that the visitors when appointed, being usually derived from the social class of the employers, performed their duties in a most perfunctory manner. Nevertheless its enactment was of great importance for it re-established that the State had a right, indeed a duty, to supervise factory life.

The next half century was a period of almost unparalleled political activity and agitation in which people like Michael Sadler, Robert Owen, Richard Oastler, Parson Bull of Byerley, Lord Ashley (later Shaftesbury), and many others espoused the cause of, in particular, the factory children. It was a period of great social distress and great economic upheaval, a period when people in large numbers were leaving the countryside to live in and create cities; a period when the old social order was breaking up and there was no clear vision of what the future held, a period when men and women tended to be depersonalized and were being forced into the discipline of the machine. John Hind, a partner in Mulholland's mill in Belfast, giving evidence to the Royal Commission of 1833, said 'The people here are more irregular in their habits of punctuality and they are as yet scarcely accustomed to the Factory System' ${ }^{13}$

When I accepted the invitation to deliver this lecture, knowing that it would be heard by this audience in Dublin, I sought to discover if conditions or circumstances in Ireland might have had any influence on the continuing story of factory legislation in these islands. I should have known better-for the impact of the industrial revolution was not felt in Ireland for many years after its evils were apparent to all, especially in northern England. It is quite interesting to read the evidence given to the 1833 Factory Commission in Belfast. It paints a picture which is very much less discreditable than that of the dark satanic mills of Lancashire. True, James Stuart, who took the evidence (and who later became one of the early factory inspectors in Ireland) in his report, said that Crossan's mill in Belfast was 'one of the worst specimens of cotton mill in point of general arrangement $I$ have seen 
anywhere and ought to be indicted but that of Boomer \& Co. is the reverse-although not without grounds for criticism' ${ }^{15}$ A colleague of Stuart, Mr. Mackintosh, took the evidence at Mulholland's mills and his comment was, 'This is a very favourable specimen of the lately erected mills in point of internal arrangement and ventilation and arrangements for cleanliness. A medical gentleman visits the works at the instance of the proprietors, twice a week..$^{15}$ In point of fact we find that elsewhere in Ireland doctors were engaged by employers to look after their workpeople. John Martin, in his evidence, refers to a Dr. Wilson at Stevenson's mill, and James Stuart took evidence from a Mr. Shaw 'who is the medical practitioner at Killyleagh whose professional services are paid for by the company for all the workers whatever their complaint', ${ }^{16}$ and if one looks at the evidence about flogging (and it is clear that enforcement of discipline by this means was the rule elsewhere) it seems to have been used in Belfast only in exceptional circumstances. John Hind, to whom I have already referred, said 'It does not matter what the offence is, positive instructions are given to overlookers not to lift a hand against a child'. Similar evidence was given elsewhere in Ireland. There was, however, one statement which puzzled me. It was made by Richard Reade, ${ }^{17}$ the manager of Whiteabbey Mill, 'no corporal punishment but by a pair of light taws is allowed but never except in extreme cases':- the Commission goes on 'he, Mr. Reade, thinks the people are very healthy, but he cannot say so much for their morals: that he considers the people as sober but wherever so many females are congregated together he conceives that their morals are not so strict'.

It is not my claim that in Ireland at this time (or, indeed, at any time) all is sweetness and light. I am simply reiterating what I should have known at the outset, that we in Ireland had very little influence on early factory legislation.

The fact was that in the main our industry was domestic in character or, at most, primitive in its sources of power. Gribbon ${ }^{18}$ states that the most striking feature of the Ulster countryside in the period $1750-1850$ must have been its intense activity 'for water power was harnessed to all kinds of uses long after it had been replaced by steam in England -and the reason is not far to seek. Marshall, ${ }^{19}$ the great flax spinner (1789-1885), commented in 1825 that the coal which cost him $£ 1850$ in Leeds would have cost him $£ 9000$ in Belfast.

It is not uncommon to find sophisticated folk of the 20th century sneering at the alleged pomposity, hypocrisy, and alleged cocksureness of the Victorian, but there is no doubt that our forbears had a selfconfidence and a will to work which today we lack. The first report of the Central Board was presented on 25 June 1833, only nine weeks after the com- mission had been set up (Commissions had been sent to take evidence in all parts of the kingdom instead of what had formerly been the practicethat of bringing witnesses to London)-nor was the Government of the day slow to act, for on 9 August 1883 there was introduced and Parliament passed 'An Act to regulate the labour of Children and Young Persons in the Mills and Factories of G.B.'.

It would be a fascinating exercise at another time to attempt to describe all the currents and crosscurrents which brought this Bill to the Statute Book. For many years the Irish Members had profound influence on British legislation; their supreme interest was to have the Act of Union repealed and to obtain for the Catholics and nonconformists relief from oppression. All else was of minor consideration. It will not surprise you, therefore, to learn that Dan O'Connell, the great emancipator, voted against the Bill. There is little doubt that he had made a bargain with the Liberals, who opposed both this and the Ten Hour Bill. You might think that politics nowadays are robust enough. Listen to this-Blackwood's Edinburgh Magazine, ${ }^{20}$ referring to O'Connell, said 'The Sordid Judas of these days betrayed them for gold. Three days after the traitor had fulfilled the conditions of the contract-a purse of $£ 700$ from the Unitarian and Dissenting Mill owners and others was presented to him. It had been kept back . . . until the noxious reptile had acquitted his engagement'. Richard Oastler $^{21}$ felt equally indignant and said of O'Connell, 'He voted against the friends of the factory children and received his reward-the "Blood Money" paid to him by the Liberal tyrants'. The intricacies of Irish politics have always baffled our neighbours!

This, of course, is of only passing interest. Peel's Act of 1802 had required that apprentices should receive some measure of instruction during working hours but this affected only a small proportion of the children employed in mills and factories. As late as $\mathbf{1 8 4 2}$ one of those taking evidence for the Children's Employment Commission, T. Martin, Esq. ${ }^{22}$ reported that in the coal mines in Co. Tyrone young people appear to be employed as early as 8 or 9 years of age and he goes on to suggest that 'parents are pushing their children into Colliery employment at an earlier age, because of the legal restriction from sending them to the neighbouring factories in which they would be exposed to far less hardship and hazard'. On the other hand, of course, must be mentioned the interesting comment of another commissioner, Mr. Roper, ${ }^{22}$ on the young workers of the Dromagh colliery: 'Their appearance was very healthy: they said their work was hard and that they must live well.' 'In the coal mines of Ireland a fixed time appears to be allowed at least for dinner and it was stated by one witness 
that at the Dromagh Mines, the extraordinary time of two hours is allowed for this meal and that the workpeople ascend the shaft to eat it; a custom, as far as it is prevalent, quite peculiar to this part of the U.K.' The Act of 1833 applied to all boys and girls in the textile industry and in it we see the first faint glimmering of the idea of an educated working class. Another significant feature was the creation of a special department of central government for the purpose of administering the Act-the embryo Factory Department. Mr. (later Sir Edwin) Chadwick is credited with this proposal but it is difficult in reading the papers of this period to resist the notion that Leonard Horner was responsible for the emphasis on education.

Leonard Horner ${ }^{23}$ came from a distinguished Edinburgh family. His father was a linen manufacturer and his brother Francis an influential member of Parliament representing St. Mawes. Educated at Edinburgh High School and Edinburgh University where he studied chemistry, Leonard soon became well known as a mineralogist and geologist and in 1808 was elected a Fellow of the Geological Society of which he later became President. Five years later he became a Fellow of the Royal Society. After some years in London he returned to Edinburgh and in $\mathbf{1 8 2 1}$ founded the School of Arts there for the instruction of mechanics and thus, according to the great Lord Cockburn, was 'indirectly the founder of all such institutions'. In 1827 Horner was invited to London to assist in organizing the London Institution and in the following year became warden of London University at its opening. He resigned this office in 1831 partly on account of ill health and went with his family to live at Bonn where he continued his studies in geology. In 1833 he was appointed one of the commissioners to enquire into the employment of children in factories and he was until 1856 one of the chief inspectors under the Factories Acts. One has only to consider his career, the range of his interests, his association with educational institutions, or one need only read his letters to his family collected in a memoir by a devoted daughter, or the pamphlets ${ }^{24}$ he wrote outlining in detail but in simple terms the educational requirements of the 1833 Act, to realize how deeply committed Leonard Horner was to the education of the common people. By 1835 he was becoming disillusioned about the effectiveness of the Act but in his Report he still insisted, perhaps in a lower key, 'I am convinced of the paramount necessity of legislative interference to prevent the children in the factories from growing up in a state of barbarous ignorance'. ${ }^{25}$ Such was the man who as one of the first four factory inspectors brought his lively cultured intelligence to bear for several years on the problems of industrial life, especially as they affected the young people of this country from 1833 until 1836 when the factory districts were reorganized. The northern part of Ireland was only part of his responsibility for his district included also the whole of Scotland, Cumberland, Westmorland, Durham, and Northumberland. Nevertheless he made his first visit to Ireland within a very few months of his appointment and in his letters to his family from Belfast he writes of the good reception he had there from the mill owners and 'their willingness to cooperate in the education of the children' ${ }^{26}$ Perhaps he was unduly influenced in Belfast by a kindred spirit, Mr. Lepper, who not only was manager of Stevenson's mills but was also secretary of Belfast Academy-the first school for secondary education in Belfast-for the following year both Horner and Howell, the inspector for Southern Ireland, reported that 'nowhere were the educational provisions of the Act complied with' ${ }^{27}$ Horner returned to Ireland in June 1835 and, judging by his letters and reports, he revelled in his work and his enjoyment of the countryside. Travelling long distances by pony and trap or horse and sidecar over poor roads, he took his opportunities for meeting and observing many interesting people. On 5 June 1835 , he found himself in a little village in the Mourne mountains, Hilltown, and was invited to dinner at the home of the local doctor, Dr. McDonnell. There Horner met Dr. Crolly, the Catholic Bishop of Down, who had just been elected Archbishop of Armagh and whose friendly spirit and great scholarship greatly impressed him. A day or two later he was in Killyleagh, some 30 miles away, inspecting a cotton factory (which he found in the highest order) and we learn that Mr. Martin, the owner, personally drove him over to Downpatrick some eight miles away where he hired a car to bring him to Castlewellan, the site of the first steam-powered mill in Ireland. There he was astonished that flax could be spun into such fine yarn as would make cambric and was lunched by the owner, Mr. Murland. Horner was a man not only of great learning but obviously of great tact. ${ }^{28}$

The 1833 Act (passed the year after the great Reform Act) not only made provision of sorts for the elementary education of children and the appointment of factory inspectors, it introduced surgeon's certificates as a means of verifying age. W. R. Lee, ${ }^{28}$ in his brilliant, illuminating, and thoroughly documented article 'Robert Baker: The First Doctor in the Factory Department', has outlined the story of the early certifying surgeons and the problems with which they were confronted so it is not necessary for me to recapitulate. Baker himself was attacked by an alderman Sadler in a speech reported in the Birmingham Daily Post ${ }^{29}$ of 16 October 1869 wherein it was alleged that the assiduity with which he enforced the Factory Act was due to the fact that Baker pocketed the fines 
for successful prosecutions. Baker ${ }^{30}$ thereupon wrote to the Home Office asking permission to prosecute an action for slander because in fact the fines were dispensed for the upkeep of the school system. Suffice it to say that since their appointment there has been agitation, which flared up from time to time, to have the system abolished. Sometimes the attack was on individual surgeons whose probity was held in question - a Dr. Shearman of Rotherham was dismissed following complaints by an inspector (Redgrave). On 9 January 1854 Redgrave $^{31}$ wrote to Hon. Henry Fitzroy, M.P., at the Home Office, 'and I would beg to state that it is by no means difficult with the exercise of common observation to determine the age of children, that at the age most especially of 13 certain well defined physiological conformations appear in regard to teeth, voice, aspect etc. which are almost accurate indication of the attainment of that age, that if certifying surgeons were to pronounce their opinion upon observation alone and to close their ears to the representations of those interested in the passing of the children, they would seldom err ... and I would unhesitatingly affirm that not one of the 300 certifying surgeons would aver that the appearance of a child under 12 could be mistaken for that of a child of 13 years of age'. Horner himself had written copiously on the subject of ascertaining the age of children by an inspection of their teeth. In a letter ${ }^{32}$ from Manchester on 30 October 1837 he writes to his wife 'I am striving with the difficulty of ascertaining the real ages of the children from physical characteristics, and have had consultations with many doctors upon the value of the teeth as a testI mean the growth of the second teeth-and I believe from all they say that it is the most unerring we can use. I am becoming rather knowing in that way for I have looked into 500 little mouths lately. I suppose it has got wind, for when the doctors and I go round the mills and call any to us that appear too young for their work, they sometimes come running with their mouths open and turn up their little heads without being told'.

Sometimes the attack came from the workpeople; the Accrington and District Trades Council ${ }^{33}$ sent a complaint to the Home Office about children having repeatedly to pay for passing the surgeon. The matter was referred to the Acting Chief Inspector of Factories who reported that the situation was even worse than that outlined for 'learners who were being paid no wages were required by occupiers to pay the fee'.

About the same time (1845) the Home Office received a memorial from the Glasgow occupiers ${ }^{34}$ that the fee should not exceed sixpence. This, of course, was opposed by the surgeons. In the event the maximum fee was fixed at one shilling plus one shilling per mile travelling expenses. If more than
10 certificates were granted the fee for each certificate was to be sixpence.

There is in the Public Record Office the dossier of correspondence initiated by Walter S. B. McLaren, M.P., ${ }^{35}$ on 9 November 1888 about the appointment of Dr. Atkinson as certifying surgeon at Crewe. It was alleged that Atkinson had been engaged by the directors of the London and N.W. Railway as works doctor and that he was receiving from them $£ 700$ per annum as remuneration. Reading between the lines it seems likely that there was a personal vendetta against Atkinson although the ostensible reason for the complaint against him was that there was 'no confidence in his fairness and impartiality'. In the end it was deemed that the doctor was 'not technically disqualified but that it was inexpedient that he continue to be a certifying surgeon and the inspector should arrange with him to resign'. It was learned subsequently that Atkinson received only $£ 80$ from the company for which he supplied drugs and dressings, and the rest of his remuneration was collected by the company from the men and passed on. It will be remembered that at first the main function of the certifying surgeon was to declare that the young person appeared not to be below the age of 10 years. This was necessitated by the fact that the compulsory registration of births did not become operative until 1837.

On 29 July 1853 a Mr. George Robinson ${ }^{36}$ wrote from Huddersfield to Lord Palmerston complaining bitterly about being called to pay a surgeon to certify 'a matter of opinion when the absolute fact at much less cost could be obtained by an application to the Registrar. There can now, My Lord be no reason why the system should continue except as a piece of patronage for the inspectors who have the right of appointment, as the real age can now be ascertained and a certificate obtained for a shilling which would last the child through life ... I need not caution your Lordship against the present attempt of designing demagogues' and protectionists' spite to so far curtail our future operations as perhaps finally to sap and undermine the very growth and foundations of trade.

$$
\begin{gathered}
\text { I am, Your Lordship's } \\
\text { very obedient servant, } \\
\text { George Robinson' }
\end{gathered}
$$

This letter was sent to Leonard Horner ${ }^{37}$ who declined to venture an opinion until he had had an opportunity of consulting his colleagues. One of these was Howell ${ }^{38}$ in Southern Ireland, and so far as I can discover this is the only occasion on which events in Ireland had any influence on the story of the certifying surgeons, for he writes from Dublin on 1 August 1853 '(I) beg to say that the Registration Act does not extend to Ireland and therefore Mr. Robinson's suggestion is inapplicable to this part of the United Kingdom, neither does it meet the case 
of Irish born children working in English factories'. And so the rôle of the certifying surgeon continued, to which was added the duty from time to time of investigating the very many accidents which perpetually marred industrial life during the 19th century. But resistance persisted, though the Factory Commission of 1875 recommended that the system be continued. It flared up acutely again in 1891, criticism coming from what nowadays we might think to be very unlikely sources. On 9 March 1891 there appeared in the Manchester Guardian a letter from T. P. Sykes, honorary secretary of the Half Time Council of Teachers from Bradford. Sykes ${ }^{39}$ complained that 'certifying surgeons are of no value' and that he had 'never known of a single instance of a child being rejected as being unfit for work'. On the other hand, a memorial from the manufacturers and employees in Smethwick ${ }^{50}$ was presented to the Home Office on 25 March 1891 in which it was testified 'that the examination by the certifying surgeon as to the physical fitness for work of young persons and children must be an essential provision in any Factory Act.' There is an interesting note pencilled in the margin of this petition to the effect that this is an important and significant document, but for the present 'I am not to be taken as accepting its arguments'. The initials I have not been able to decipher. The correspondence columns of both the provincial and national press (not to speak of the medical journals in which also appeared lengthy editorial comment) were lively on the issue but when the matter came before Parliament, The Economist ${ }^{41}$ found itself impelled to comment on 'the extraordinary ignorance displayed by the members who took part in the debate on the 2nd reading of the Bill ... for the amendment of the Factory Act'. ${ }^{41}$ It could have been written 80 years later about the debate on the late unlamented Employed Persons (Health \& Safety) Bill which sought among other things to reorganize the Appointed Factory Doctor Service.

It seems clear that with all their faults the certifying surgeons made a significant contribution to the welfare of the children of the 19th century. The problems of the 20th century are not those of ill-health and malnutrition. They are in many ways more difficult and more insidious, and other agencies are at work in their amelioration. Nevertheless, under present legislation, the appointed factory doctor is the only medical man who by statute sees the young people during the transition period from school to factory. Sometimes they are interviewed by the youth employment services, often they join youth clubs, not infrequently they come under the care of probation officers, and all too seldom (although the number is growing) they come under the influence of teachers in further education colleges. Margot Jeffreys $^{42}$ points out in her final chapter that the needs are complicated and varied, that they cannot be dealt with in 1solation and that their interaction requires a unified approach. Is it not time that we so arranged our affairs that the youth of our country instead of being dealt with in a haphazard way were cared for by a single coordinated agency in which the appointed factory doctor would play an effective part?

I wish to thank Dr. T. A. Lloyd Davies, Senior Medical Inspector of Factories, for drawing my attention to the relevant documents in the Public Record Office, and Miss Jessie B. Webster, M.A., F.S.A. Scot., A.L.A., of the Queen's University Library, for her invaluable assistance in checking the references.

Without the forbearance of my secretary, Mrs Dorothy E. Macartney, this lecture would not have been prepared for publication and I am grateful for her cooperation.

\section{References}

${ }^{1}$ Brit. med. J., (1925). 1, 46.

'Ibid. (1926). 2, 853.

Ilbid. (1940). 2, Suppl. p. 62.

'Hutchins, B. L., and Harrison, A. (1907). History of Factory Legislation, 2nd ed., pp. 1-2. King, Westminster.

'D'Arcy, C. F. (1934). The Adventures of a Bishop, p. 39. Hodder \& Stoughton, London.

Meiklejohn, A. (1959). Industrial health-Meeting the challenge. Brit. J. industr. Med., 16, 1-10.

742 George III C73 Sec 10.

${ }^{8}$ Stuart, J. A. Public Record Office O.S. 2864

'Bain, Alex. Public Record Office O.S. 2864.

${ }^{10}$ Home Office (Under Secretary). Public Record Office O.S. 2864.

${ }^{11}$ Horner, Leonard. Public Record Office O.S. 2844.

12W.H.O. Constitution. 1946. p. 3. Geneva.

${ }^{13}$ Hind, John. Evidence taken by Mr. Mackintosh for Royal Commission 1833 on Employment of Children in Factories, p. 89.

${ }^{14}$ Stuart, J. A. Report of evidence taken for Royal Commission 1833 on employment of Children in Factories, pp. 89-93 and p. 127.

${ }^{15}$ Mackintosh, R. Report of Commissioners 1833 on Employment of Children in Factories, p. 90.

${ }^{16}$ Martin, John. Evidence taken by Mr. J. A. Stuart for Royal Commission 1833 on Employment of Children in Factories, pp. 127-133.

${ }^{17}$ Reade, Richard. Evidence to Royal Commission 1833 on Employment of Children in Factories, p. 133.

${ }^{18}$ Gribbon, H. D. (1969). The History of Water Power in Ulster, p. 188. David \& Charles, Newton Abbot.

${ }^{19}$ Rimmer, W. G. (1960). Marshalls of Leeds, Flax-Spinners 1788-1886, p. 131. University Press, Cambridge.

${ }^{20}$ Blackwood's Edinburgh Magazine (1836). No. 249, Vol. 40, The cotton manufacture, and the factory system (pp. 100121).

${ }^{21}$ Oastler, R. (1836). The Factory Question and the Factory Agitation. Henry Hetherington, London.

${ }^{22}$ Martin T. (1842). 1st Report of Commissioners on Employment of Children in Mines, pp. 23-24.

${ }^{23}$ Dictionary of National Biography. (1891). Vol. 27, London, pp. 371-372. Smith Elder, London.

${ }^{24}$ Horner, Leonard. 'Factories Regulation Act 1834 Explained', sec. 20-21. David Robertson, Glasgow.

${ }^{25}$ Horner, Leonard. (1836). Factory Inspector's Report, p. 158. 
${ }^{26}$ Horner, Leonard. (1890). Memoir . . . Letters, edited by K. M. Lyell, p. 328. Privately printed, London.

${ }^{27}$ Factory Inspectors' Reports 1834, p. 431.

25 -ee, W. R. (1964). Robert Baker: The first doctor in the Factory Department. Parts I and II. Brit. J. industr. Med., 21, 85-93, 167-179.

${ }^{29}$ Birmingham Daily Post, Oct. 16, 1869. Public Record Office HO OS8259.

${ }^{30}$ Baker, R. Letter in Public Record Office HO OS8259/4.

${ }^{31}$ Redgrave, A. (1854). Correspondence at Public Record Office HO45 OS5206.

${ }^{32}$ Horner, Leonard. (1890). Memoir . . . Letters, edited by K. M. Lyell, Vol. 1, p. 352. Privately printed, London.

${ }^{33}$ Accrington and District Trades Council. Public Record Office HO45 9859/B 12604.

${ }^{34}$ Home Office file at Public Record Office OS654.

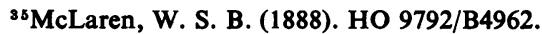

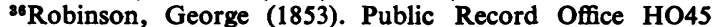
OS4771.

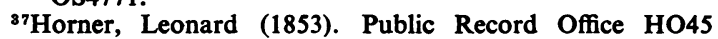
OS4771.

${ }^{38}$ Howell. (1853). Public Record Office HO45 OS4771.

${ }^{39}$ Sykes, T. P. (1891). Manchester Guardian, March 9.

${ }^{10}$ Correspondence from Smethwick. Public Record Office HO45 B1136/75.

${ }^{4}$ The Economist, undated cutting, Public Record Office HO B1136/64.

42Jefferys, Margot (1965). An Anatomy of Social Welfare Services, pp. 299-324. Michael Joseph, London.

Received for publication October 30, 1970. 